\title{
Analisis kerangka kerja, aliran, dan hambatan rantai pasokan
}

\author{
Terryna Tasya Mizani \\ STIE Ekuitas, Jl. P.H.H Mustofa 31, Bandung, 40124, Indonesia \\ E-mail: tasyaamirzaani@gmail.com
}

Anton Mulyono Azis*

STIE Ekuitas, Jl. P.H.H Mustofa 31, Bandung, 40124, Indonesia

E-mail: anton.mulyono@ekuitas.ac.id

*Penulis Korespondensi

Submitted: Oct 5, 2021; Reviewed: Oct 9, 2021; Accepted: Nov 10, 2021

\begin{abstract}
This study aims in determining the implementation of supply-chain framework; identifying the flow of goods, money, and information, as well as the problems and factors that influence them. The research object is the supply chain management of two aircrafts at PT Dirgantara Indonesia (Persero). The descriptive analysis method is used with a qualitative approach as the result of interviews and observations to be analyzed to answer the research questions. The results indicate that the running framework consists of nine activities, the existence of a linkage to each flow, where the punctuality of payment by the customer will facilitate the flow of the goods itself, also the timeliness of delivery by suppliers in obtaining materials can shorten production time, flow of goods, and flow of money. Money will not run smoothly without the accurate flow of information and the credibility of the exchange of information. It is expected that all stakeholders need to further improve coordination and collaborate to create products with the right service quality, quantity, time, and place.
\end{abstract}

Keywords: flow of goods; flow of information; flow of money; framework; supply chain management

Abstrak: Tujuan dari penelitian yaitu untuk mengetahui kerangka implementasi manajemen rantai pasokan, mengidentifikasi aliran barang, aliran uang, dan aliran informasi, serta masalah dan faktor yang memengaruhinya. Objek penelitian adalah manajemen rantai pasokan di PT Dirgantara Indonesia (Persero) yang meliputi arus barang, arus uang, dan arus informasi. Metode deskriptif dengan pendekatan kualitatif digunakan pada penelitian ini. Data yang diambil merupakan hasil wawancara dan observasi, kemudian dianalisis sehingga diperoleh hasil yang dibutuhkan. Hasil penelitian menunjukkan bahwa running framework terdiri dari sembilan aktivitas, adanya keterkaitan pada setiap aliran, yang mana ketepatan waktu pembayaran oleh pelanggan akan memudahkan arus barang itu sendiri, juga ketepatan waktu pengiriman oleh pemasok dalam memperoleh bahan dapat mempersingkat waktu produksi, aliran barang, dan aliran uang. Uang tidak akan berjalan lancar tanpa aliran informasi yang akurat dan kredibilitas pertukaran informasi. Diharapkan seluruh pemangku kepentingan dapat lebih meningkatkan koordinasi dan kolaborasi untuk menghasilkan produk dengan ketepatan pada layanan, kualitas, kuantitas, waktu, dan tempat.

Kata kunci: arus barang; arus informasi; arus uang; kerangka kerja; manajemen rantai pasokan 


\section{PENDAHULUAN}

Pengelolaan rantai pasokan merupakan serangkaian proses yang tidak mudah (Sugara \& Azis, 2020). Banyak pihak yang terlibat di sepanjang rantai pasokan dan tentunya berbagai faktor perlu dipertimbangkan, termasuk upaya untuk membuat seluruh proses dan aliran di sepanjang rantai pasokan dapat memenuhi kriteria tepat waktu, tepat jumlah, tepat biaya, dan tepat mutu (Chopra \& Meindl, 2013). Penelitian ini diharapkan dapat mengidentifikasi secara tepat kriteria-kriteria tersebut, melalui penelusuran rantai pasokan terkait. Untuk itu diperlukan manajemen rantai pasokan yang terintegrasi guna memenuhi kebutuhan pasokan bahan baku, proses produksi yang lancar, dan pengiriman sesuai jadwal hingga ke konsumen. Suatu rantai pasokan memiliki tiga alur yang harus dikelola (Pujawan \& Mahendrawathi, 2017; Sherlywati, 2017). Pertama aliran barang, yang mana aliran bergerak dari hulu ke hilir berupa barang dari pemasok, produsen, agen hingga konsumen, dan sebaliknya untuk aliran balik atas retur produk, layanan, pembuangan, dan daur ulang. Kedua adalah aliran keuangan atau sejenisnya, meliputi jadwal pembayaran, penetapan kepemilikan, dan transfer. Ketiga adalah aliran informasi, meliputi prediksi kebutuhan, transmisi pesanan atau permintaan, dan laporan transaksi.

Selanjutnya pengelolaan ketiga aliran tersebut, terutama aliran informasi, juga memerlukan fondasi yang kuat agar dapat menghasilkan aliran yang dapat memperlancar seluruh proses (Azis \& Azis, 2013), dan dirumuskan dalam suatu kerangka kerja rantai pasokan yang merupakan struktur dalam mengembangkan, merancang, menggunakan, dan menilai secara sistematis (Vanichchinchai, 2019). Tujuan dari kerangka kerja ini yaitu untuk menghasilkan manfaat yang maksimal dalam memenuhi kebutuhan pelanggan (Chopra \& Meindl, 2013). Adapun kerangka kerja digunakan untuk efisiensi dan stabilitas rantai pasokan melalui upaya dalam menggabungkan sumber-sumber daya, biaya inventori, dan keputusan kesesuaian konfigurasi rantai pasokan (Albab \& Azis, 2021). Dalam kegiatan operasional ini, sistem distribusi yang dimiliki perusahaan cukup kompleks, dengan demikian mengharuskan aktivitas yang serius dalam mengidentifikasi ketepatan rantai pasokan.

Lebih jauh lagi, hambatan yang terjadi pada rantai pasokan dapat menyulitkan terbentuknya keuntungan yang diharapkan. Selain faktor teknologi dan dinamika siklus produksi (Irjayanti \& Azis, 2017; Heizer et al., 2017), kekurangan bahan baku, peningkatan biaya pada proses produksi, penundaan penerimaan bahan baku, serta ketidakpastian permintaan sebagai dampak ketidakakuratan peramalan dapat menjadikan aliran rantai pasokan tidak lancar. Selain itu, hambatan-hambatan tersebut seringkali mengakibatkan bullwhip effect, terkait information failure, chain complexity, product proliferation, dan economies of scale (Min, 2015). Ditambah lagi perencanaan dan peramalan yang tidak akurat seringkali berakhir dengan ketidakseimbangan antara supply dan demand yang berdampak pada persediaan bahan baku berlebih maupun kekurangan atau run out stock (Widyacantika \& Azis, 2020).

Selanjutnya, beberapa hambatan pada perusahaan, yaitu keterlambatan pembayaran pada termin tertentu, yang pada gilirannya dapat menghambat proses produksi, belum efektifnya proses pemesanan yang saat ini dilakukan secara manual atau by email yang juga mengakibatkan peningkatan waktu tunggu dan biaya-biaya yang tidak efisien. Secara khusus, pada aliran barang terjadi waktu tunggu yang terus berpotensi meningkat menjadi lebih lama pada tiga jenis bahan baku, yaitu: bahan baku metal, non-metal, dan komponen standar, seperti ditunjukkan pada Tabel 1.

Tabel 1. Persentase kendala lead-time

\begin{tabular}{lc}
\hline \multicolumn{1}{c}{ Jenis Bahan Baku } & Persentase Lead Time \\
\hline Raw Material Metal (RMM) & $30 \%$ \\
Raw Material Non Metal (RMN) & $25 \%$ \\
Standard Part (STD) & $10 \%$
\end{tabular}

Sumber: Hasil pengolahan data (2020)

Tabel 1 menunjukkan adanya permasalahan lead-time, yaitu terkait dengan jadwal pemenuhan bahan baku yang mengalami waktu tunda. Pada raw material metal terdapat kenaikan waktu tunggu menjadi lebih lama sebesar 30 persen, raw material non-metal sebesar 25 persen, dan standard part sebesar 10 persen. Untuk itu penelitian ini bertujuan guna: (1) mengidentifikasi framework manajemen rantai pasokan perusahaan; (2) menganalisis aliran barang, uang, dan informasi, dan persoalan yang terjadi; serta (3) mengidentifikasi faktor-faktor penyebab terjadi hambatan dan solusi dalam penerapan manajemen rantai pasokan perusahaan. Dengan tema aliran rantai pasokan, penelitian ini merupakan 
penelitian yang baru dilakukan di perusahaan terkait. Selain itu juga terdapat kebaruan dari analisis aliran-aliran yang relevan di sepanjang rantai pasokan. Kemudian, diharapkan penelitian ini memberikan kontribusi secara teoretis kepada body of knowledge keilmuan manajemen rantai pasokan berupa ketersediaan informasi atas seluruh aliran di sepanjang rantai pasokan produk terkait, mulai dari aliran barang, aliran uang, serta aliran informasi. Selanjutnya secara praktis, diharapkan penelitian ini memberikan kontribusi atas lancarnya seluruh aliran, sebagai dampak atas teridentifikasinya hambatanhambatan yang ada di sepanjang rantai pasokan, serta disampaikannya alternatif solusi atas hambatanhambatan tersebut. Selain itu diharapkan juga terjadi koordinasi yang sinergis serta kolaborasi yang harmonis pada setiap pemangku kepentingan guna menghasilkan produk dengan jumlah dan mutu yang sesuai, serta dengan pengiriman yang juga tepat waktu.

\section{METODE}

Objek penelitian meliputi manajemen dan aliran rantai pasokan perusahaan, yang meliputi aliran barang, uang, dan informasi. Metode yang digunakan yaitu analisis deskriptif dengan pendekatan kualitatif (Sugiyono, 2019). Analisis deskriptif dilakukan guna mendapatkan penjelasan objektif, perbandingan, dan penilaian yang digunakan dalam pengambilan keputusan, antara lain: mendapatkan fakta tentang hambatan pada ketiga aliran rantai pasokan perusahaan, hubungan antar variabel, dan dampak yang terjadi atas persoalan yang mengemuka. Identifikasi permasalahan dilakukan melalui wawancara dan observasi langsung maupun tidak langsung pada pihak-pihak terkait, melalui pemanfaatan teknologi informasi, terutama menggunakan media online meeting dan telepon. Dua produk yang menjadi fokus penelitian adalah jenis pesawat yang diproduksi perusahaan dan data terkait bahan baku, proses dan kendala-kendala proses, hasil, serta informasi-informasi relevan lainnya. Dari pengamatan dan wawancara ini, didapatkan gambaran sistematis yang didukung dengan fakta-fakta yang terurai pada bagian berikut dari penelitian ini.

\section{HASIL DAN PEMBAHASAN}

Dari hasil penelitian, didapat kerangka rantai pasokan yang diterapkan perusahaan. Selain terkomputerisasi, sistem aplikasi yang digunakan adalah SAP (System Application and Product). Implementasi ini berguna untuk merinci perencanaan, menindaklanjuti pesanan, pelaporan kemajuan pekerjaan, dan master planning. Kerangka kerja ini secara teori dapat membantu memperbaiki efisiensi dan stabilitas rantai pasokan perusahaan. Hal ini terjadi karena adanya penggabungan atau integrasi segenap biaya sediaan, sumber, dan keputusan-keputusan dalam mengatur konfigurasi mata rantai di sepanjang rantai pasokan (Puspita \& Arvianto, 2015).

Terdapat sembilan aktivitas dalam kerangka kerja rantai pasokan perusahaan, seperti diperlihatkan pada Gambar 1. 


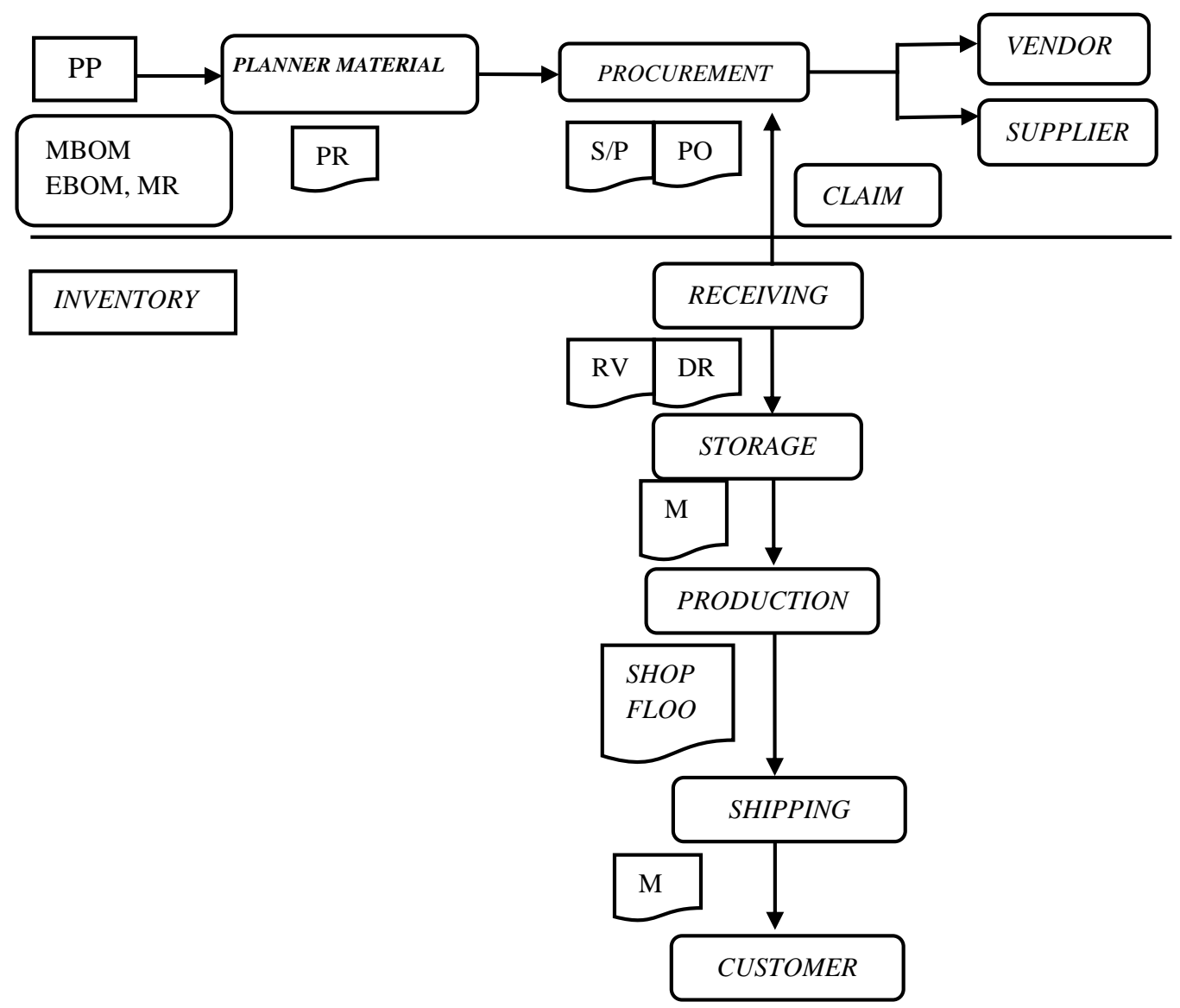

Keterangan:

PP: Production Planning

PR: Purchase Request

S/P: Surat Pembelian

PO: Purchase Order

RV: Receiving Voucher

DR: Discrepancy Report

MT: Material Ticket

MD: Material Delivery

Gambar 1. Framework rantai pasokan perusahaan

Sumber: PT Dirgantara Indonesia (Persero) (2015)

Secara ringkas, kerangka kerja tersebut terurai sebagai berikut: (1) Production Planning, yaitu proses untuk menginput bill of material dari manufacturing (MBOM), Engineering Bill of Material (EBOM), dan Material Requirement (MR). Hal ini dilakukan guna mengetahui tingkatan atau levelling dari production planner; (2) Material Planner, yang membuat daftar permintaan material yang dibutuhkan; (3) Pihak procurement membuat daftar pembelian (Purchase Order atau PO) dari vendor atau pemasok, untuk melakukan negosiasi harga dan pembelian barang atau material; (4) Negosiasi harga dan pembelian barang; (5) Penerimaan dan pemeriksaan kelengkapan dokumen dan bahan. Jika lolos pemeriksaan, maka akan dibuatkan RV (Receiving Voucher) dan selanjutnya disimpan ke gudang, jika tidak maka akan dibuatkan DR (Discrepancy Report) dan dikembalikan kepada material planner untuk keputusan apakah material diterima atau dikembalikan ke pemasok; (6) Penyimpanan, yang mana bahan-bahan yang telah lolos seleksi, dikirimkan ke gudang disertai dokumen Material Ticket; (7) Penggunaan bahan untuk proses produksi pada aktivitas ke-tujuh ini disesuaikan dengan kebutuhannya; (8) Shipping, yaitu proses akhir guna mengirimkan pesawat; serta (9) Pengiriman yang dilengkapi dengan Material Delivery. 
Selanjutnya, Gambar 2 memperlihatkan diagram aliran rantai pasokan perusahaan. Aliran barang, uang, dan informasi yang terjadi pada perusahaan merupakan rangkaian aktivitas yang terintegrasi mulai dari bahan baku hingga konsumen, dan terkait tiga aspek yaitu sumber, proses produksi, dan pengiriman produk. Hasil ini menunjukkan cakupan kegiatan manajemen rantai pasokan atas seluruh aktivitas yang terjadi terkait di sepanjang rantai pasokan perusahaan yang menggambarkan secara utuh keseluruhan proses pengadaan dan penyelesaian pemesanan (Sherlywati, 2017; Koblen, 2013).

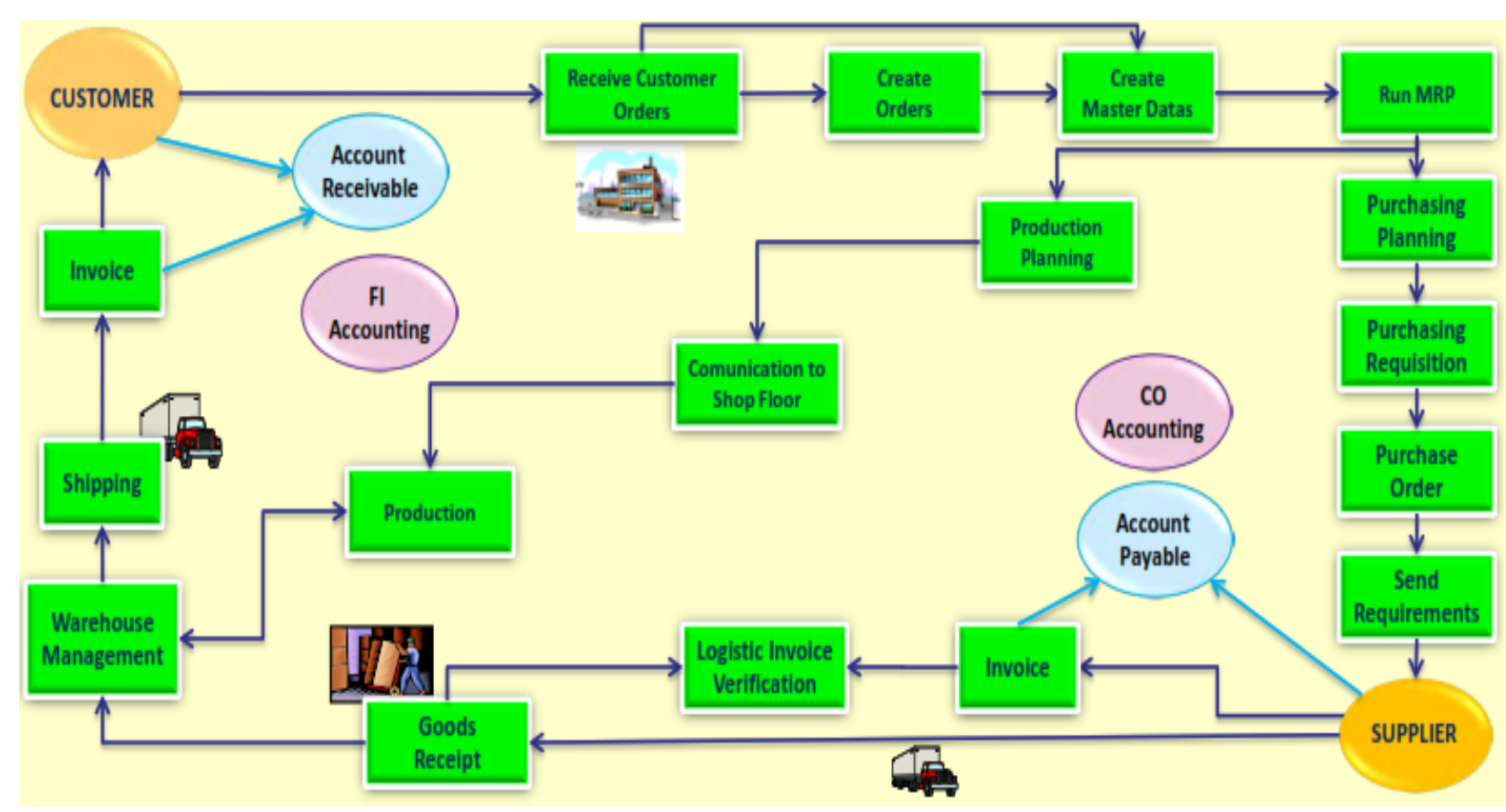

Gambar 2. Proses pengadaan dan penyelesaian pemesanan

Sumber: PT Dirgantara Indonesia (Persero) (2015)

Secara ringkas, proses pengadaan dan penyelesaian pesanan dapat dikelompokkan dalam tiga rangkaian aktivitas utama, yaitu proses pengadaan dan pihak-pihak terkait, antisipasi proses bahan baku yang kosong atau tidak tersedia di gudang, dan running MRP (Material Requirement Planning) saat persediaan terkendali.

Aktivitas utama pertama terdiri atas beberapa kegiatan sebagai berikut: (1) Penetapan pelanggan yang terdiri atas pelanggan domestik dan juga internasional. Pelanggan domestik antara lain: BPPT, TNI AU, Kepolisian RI, PT Deraya Air Charter, PT Airfast, PT Pelita Air Services (PAS), SMAC (PT Sabang Merauke Raya Air Charter), TWA (PT Trans Wisata Prima Aviation), dan lain-lain, sedangkan pelanggan internasional (worldwide customer) terdiri dari: perusahaan di Korea Selatan, Turki, Uni Emirat Arab, Pakistan, Air Venezuela, UAE Airforce, Royal Brunei Airforce, dan lain-lain. Pelanggan PT Dirgantara Indonesia (Persero) dikelola oleh bagian penjualan saat menerima pesanan pelanggan, selanjutnya pelanggan melakukan komunikasi dengan bagian penjualan untuk penawaran harga. Alur informasi pemesanan produk dikelola oleh bagian Receive Customer Order (RCO). Dalam tahap ini, pelanggan akan membuat pesanan dan didokumentasikan dalam PO; (2) Receive Customer OrderCreate Orders. Setelah pesanan konsumen diterima dan telah didokumentasikan dalam PO, maka pesanan selesai dibuat (Create Orders). Dalam tahap ini dilakukan pemrosesan daftar permintaan pembelian dan pembuatan pesanan pembelian oleh pelanggan yang dilakukan oleh bagian Material Master (MM); (3) Create Master Data. Dalam tahap ini, Material Master (MM) mengelompokkan dan menetapkan apa saja jenis dan tipe material yang dibutuhkan sesuai dengan pemesanan; (4) Run MRP. Setelah itu, tahap selanjutnya adalah Run MRP, yang mana dalam tahap ini dilakukan pengisian PO, penerimaan pesanan pengiriman persediaan (Order Transfer Stock) dan penjadwalan (Schedule Lines) berdasarkan data yang diterima dari bagian Material Master (MM), yang bertujuan untuk memperkirakan kebutuhan jumlah bahan baku dan waktu atau jadwal pengiriman. Pada kegiatan ini dilakukan pemeriksaan material yang dibutuhkan untuk produksi pesawat. Jika masih ada persediaan 
material di gudang, maka tidak perlu dilakukan pemesanan, maka tahap selanjutnya adalah perencanaan produksi (production planning). Namun bila stok material tersebut kosong, maka dilakukan pemesanan sesuai dengan spesifikasi yang diinginkan seperti dimensi material dan bentuk material, dan tahap selanjutnya adalah purchasing planning.

Aktivitas utama kedua yaitu saat material tidak tersedia di gudang. Aktivitas yang dilakukan antara lain: (1) Purchasing Planning, yang mana dilakukan pengontakan pemasok guna memenuhi kebutuhan sesuai dengan spesifikasi yang diinginkan; (2) Selanjutnya melakukan permintaan pembelian (Purchase Requisition) atas bahan baku yang dibutuhkan; (3) Purchase Order_Send Requirements, yang mana purchasing requisition diserahkan ke pembeli dan membuat PO. Dilanjutkan dengan mencari pemasok guna pembelian barang, diikuti dengan mengirimkan persyaratan berupa berkas atau aspek dokumen untuk memenuhi persyaratan; (4) Supplier-Invoice-Logistic Invoice Verification. Pemasok menerima PO dari bagian pengadaan (procurement) yang diberikan oleh admin berupa daftar pembelian barang dan pembayaran ke pemasok, dan menerima faktur pembelian barang bukti transaksi dari pemasok dan data hasil produksi dari bagian produksi, dilanjutkan dengan pelaporan ke bagian keuangan, dan aktivitas terakhir; serta (5) Goods Receipt, yang mana dilakukan setelah dari tahap pemsok, yang mana bagian mutu menerima pembelian barang, surat jalan, dan faktur barang dari pemasok, yang kemudian melakukan pengecekan kesesuaian barang. Setelah itu, bagian gudang (Goods Receipt) menerima barang dan data barang dari bagian mutu, kemudian bagian gudang memberikan bukti terima bahan baku kepada bagian keuangan.

Tahap selanjutnya setelah MRP dijalankan, saat material terkendali, aktivitas-aktivitas yang dilakukan meliputi: (1) Production Planning, yang terdiri dari tiga aktivitas yaitu rencana produksi dengan membuat Make to Order (MTO), Work Breakdown Structure (WBS), Network and Aircraft Table (NAT), dilanjutkan dengan aktivitas kedua untuk perencanaan kapasitas, dan aktivitas ketiga yaitu proses produksi material termasuk aktivitas konsumsi material; (2) Communication to Shop Floor, yang mana pada tahap ini dilakukan konversi atas aktivitas penyelesaian perencanaan produksi berupa work order dan penjadwalannya, kebutuhan kapasitas, ketersediaan bahan, melakukan rilis atas proses produksi, serta mendokumentasikan penerimaan barang jadi maupun setengah jadi, dan penyelesaian work order. Pada tahap ini, penyelesaian permintaan produksi disimpan dan dikomunikasikan pada status sistem. Informasi berupa status bahan, status stasiun kerja, rute-rute yang harus dilewati, dan proses lanjutan yang dibutuhkan; (3) Tahap produksi sesuai dengan perencanaan dan pemesanan; (4) Warehouse Management, yaitu pengelolaan perpindahan barang dari gudang maupun keluar gudang guna secara otomatis mempercepat proses lead time, mengetahui transaksi inventory, selain itu dilakukan berbagai proses penerimaan dan put away, dispatching, penerimaan stok, dan pelaporan; (5) Shipping, yang terdiri dari dua kegiatan yaitu pergerakan barang di internal material dan pengeluaran material, serta pengiriman barang ke eksternal perusahaan, dan berimplikasi pada berkurangnya persediaan di gudang; (6) Membuat faktur-faktur (invoice) yang berhubungan dengan informasi tagihan, antara lain jumlah tagihan, total pajak, biaya angkut, vendor penerima dan informasi-informasi lainnya yang lebih mendetil; serta (7) Pelanggan menerima hasil produksi berupa pesawat, helikopter maupun material yang telah dipesan kepada PT Dirgantara Indonesia (Persero).

Selanjutnya permasalahan yang terjadi yang terjadi pada rantai pasokan perusahaan yang berhasil teridentifikasi yaitu: (a) Pada aliran barang, yang mana aliran belum maksimal, sehingga belum mampu memenuhi pengiriman barang tepat waktu kepada customer. Hal ini disebabkan terjadinya kekurangan bahan baku sebagai dampak lead time yang lebih lama dalam pemesanan material kepada pemasok. Produk yang tidak sampai ke konsumen sesuai dengan jadwal yang telah direncanakan, menimbulkan biaya tambahan, yaitu biaya penalti, dan hal ini akan mengurangi keuntungan perusahaan; (b) Pada aliran uang, yaitu terdapat dua pelanggan yang terlambat melakukan pembayaran. Pelanggan pertama terlambat melakukan pembayaran termin keempat yaitu pada tahap fuselage integration ke tahap delivery aircraft. Pelanggan kedua telat melakukan pembayaran pada termin ketiga yaitu pada tahap basic airframe ke tahap basic system installation; serta (c) Pada aliran informasi, yang mana perusahaan belum melakukan pengembangan website pada bagian pengadaan dan pemasok. Pada proses pengadaan atau pemesanan material, interaksi pemesanan dilakukan melalui email yang kurang efektif karena konfirmasi email yang memakan waktu lama, hal ini juga menyebabkan adanya proses lead time yang meningkat dan ketidakefisienan pembiayaan.

Adapun faktor-faktor penyebab terjadinya hambatan serta solusi atas hambatan tersebut adalah sebagai berikut. 
a. Perusahaan menghadapi kondisi pemasok yang didominasi perusahaan pada bidang rekayasa, rancang-bangun, serta produksi pesawat terbang dari luar negeri. Pemasok yang saat ini bekerja sama pun berasal dari luar negeri. Hal ini menyebabkan tingginya risiko terhadap pengiriman material. Sepanjang tahun 2020-2021, faktor terjadinya keterlambatan material juga disebabkan oleh dampak pandemi Covid-19, yang mempengaruhi impor bahan baku yang selama ini kontribusinya 74 persen dari total impor, dan diprediksi akan menghambat siklus produksi. Selain itu juga berdampak pada penerimaan bahan dari luar negeri yang dibatasi hanya dua kali dalam satu minggu. Kondisi ini sangat memengaruhi keputusan pemesanan material untuk setiap proses produksi. Faktor lain yang menyebabkan semakin lama datangnya material adalah adanya perubahan pesanan terhadap jumlah material yang dipesan kepada pemasok, hal ini membuat pemasok harus menyesuaikan kembali pesanan dan menambah waktu tunggu pesanan. Solusi dalam hambatan ini adalah menambahkan jadwal pihak eksternal dalam pengiriman bahan baku, perusahaan juga harus lebih mengutamakan perbaikan untuk mengatur dan mengendalikan proses pengiriman, karena dalam proses rantai pasokan, proses perencanaan proyek harus dapat memperkirakan waktu tunda yang tidak terduga.

b. Solusi terhadap permasalahan keterlambatan pembayaran sebagai dampak keterlambatan proses, yaitu melakukan pergantian material yang seharusnya dengan material lain, yang memiliki fungsi dan karakteristik yang sama. Penyebab atas terjadinya kondisi ini antara lain habisnya persediaan material, terdapat perbedaan atas dimensi yang dibutuhkan, atau tidak ada persediaan sama sekali (no stock). Solusi ini pada sistem dikenal dengan substitusi material. Atas pengambilan keputusan terkait solusi ini, maka umumnya diadakan pertemuan antar pihak guna membahas persoalan yang dihadapi, dengan berlandaskan kontrak yang telah disepakati dan tetap bertanggung jawab atas pembayaran denda yang telah diberlakukan. Selain itu, solusi lainnya adalah melakukan konversi dana investasi untuk membeli bahan baku atau dipakai sesuai kebutuhan selagi menunggu customer membayar sisa tagihan.

c. Faktor hambatan dalam aliran informasi, yaitu kurangnya perencanaan dan strategi untuk pengembangan sistem informasi yang dijalankan tidak 100 persen serta tidak konsisten. Selain itu, adanya keterbatasan anggaran membuat pengembangan sistem informasi terhambat. Solusinya adalah melakukan pengembangan sistem informasi berbasis pengendalian logistik dan berbasis world wide web (www) yang handal dan mampu menghasilkan informasi guna mengendalikan ketepatan persediaan barang, dengan harapan, tidak terjadi kelebihan maupun kekurangan stok dalam jumlah yang besar.

Hasil ini sejalan dengan hasil penelitian terdahulu yang mana faktor penghambat dalam penerapan manajemen rantai pasokan antara lain: (a) kegagalan informasi terhadap keragaman produk, (b) ketidakpastian permintaan, (c) kesulitan dalam memprediksi dan merencanakan pemesanan, (d) fluktuasi volume produksi, kerumitan rantai pasokan, variasi produk yang menyebabkan bullwhip effect, dan (e) pemesanan dilakukan di akhir bulan, quarter atau akhir tahun, yang menyebabkan peningkatan lead time yang lebih lama (Min, 2015; Milambo \& Phiri, 2019; Puspawan \& Azis, 2019).

\section{SIMPULAN DAN SARAN}

Framework implementasi manajemen rantai pasokan pada PT Dirgantara Indonesia (Persero) terdiri dari sembilan aktivitas yaitu production planning, planner material, procurement, vendor-supplier, receiving, storage, production, serta shipping dan customer. Terdapat keterkaitan pada setiap aliran, yang mana dalam hal ketepatan waktu pembayaran oleh customer akan memperlancar aliran barang, ketepatan waktu pengiriman, memperlancar proses produksi dan ketepatan waktu produksi, yang didukung dengan informasi yang akurat dan kredibilitas pertukaran informasi. Adapun permasalahan aliran barang yaitu terjadi keterlambatan pengiriman material oleh pemasok, pelanggan terlambat melakukan pembayaran pada termin tertentu, dan belum melakukan pengembangan website pada bagian procurement dan supplier. Diharapkan seluruh pemangku kepentingan dapat lebih meningkatkan koordinasi dan kolaborasi untuk menghasilkan produk dengan ketepatan layanan, kualitas, kuantitas, waktu, dan tempat.

Penulis menyarankan untuk melanjutkan penelitian ini, terutama mengkaji ulang kebutuhan persediaan pengaman dan pemanfaatan kelonggaran kapasitas produksi, dan dilakukannya pemeliharaan internal perusahaan dengan sistem yang saat ini digunakan. Selain itu, penelitian lanjutan juga dapat 
tekait dengan sistem yang berguna untuk pengendalian persediaan dengan pengelolaan data logistik yang efektif dan akurat dalam merencanakan kebutuhan dan penggunaan barang.

\section{ACKNOWLEDGEMENTS}

Penulis mengucapkan terima kasih kepada Kementerian Pendidikan, Kebudayaan, Riset, dan Teknologi Republik Indonesia dan Sekolah Tinggi Ilmu Ekonomi (STIE) Ekuitas Bandung.

\section{REFERENSI}

Albab, R. G. M., \& Azis, A. M. (2021). Supply chain analysis for household waste treatment product from coconuts. International Journal of Advances in Engineering and Management, 3(9), 17791788. https://doi.org/10.35629/5252-030917791788

Azis, A. M., \& Azis, Y. (2013). Foundation and basic information in designing performance management system. International Journal of Innovation in Business, 2(4), 327-349. https://www.cibmp.org/journals/index-php/ijib/article/view/68/

Chopra, S., \& Meindl, P. (2013). Supply chain management strategy, planning and operation. Pearson Education

Heizer, J., Render, B., \& Chuck, M. (2017). Principles of operations management. Pearson Education Limited

Irjayanti, M., \& Azis, A.M. (2017). Implementing technology in creative industry (Benchmarking study in developed countries). Advanced Science Letters, 23 (9), 8113-8118. https://doi.org/10.1166/asl.2017.9845

Koblen, I. (2013). Selected aspects of the supply chain management in the aerospace industry. Incas Bulletin, 5(1), 135-149. https://doi.org/10.13111/2066-8201.2013.5.1.13

Milambo, D., \& Phiri, J. (2019). Aircraft spares supply chain management for the aviation industry in Zambia based on the supply chain operations reference (SCOR) model. Open Journal of Business and Management, 7(3), 1183-1195. https://doi.org/10.4236/ojbm.2019.73083

Min, H. (2015). The essentials of supply chain management. Pearson Education

PT Dirgantara Indonesia (Persero). (2015). Dokumen SAP. Bandung

Pujawan, I. N., \& Mahendrawati, E. R. (2017). Supply chain management. ITSN

Puspawan, D. H., \& Azis, A. M. (2019). The performance of the customer values perspectives and company's fund distribution. International Journal of Management and Applied Science, 5(11), 99-103. http://www.iraj.in/journal/journal_file/journal_pdf/14-616-158114801799-103.pdf

Puspita, D. E., \& Arvianto, A. (2015). Pengembangan model optimasi desain rantai pasok dengan mempertimbangkan biaya distribusi pada distribution center. Industrial Engineering Online Journal, 4(1), 1-21. https://ejournal3.undip.ac.id/index.php/ieoj/article/view/7935/7695

Sherlywati. (2017). Urgensi penelitian manajemen rantai pasok: Pemetaan isu, objek, dan metodologi. Jurnal Manajemen Maranatha, 17(2), 147-162. https://doi.org/10.28932/jmm.v17i2.800

Sugara, A. A., \& Azis, A. M. (2020). Electronic supply chain management application analysis in retail industry. International Journal of Business and Technology Management, 2(2), 45-51. https://myjms.mohe.gov.my/index.php/ijbtm/article/view/10168/4797

Sugiyono. (2019). Metode penelitian kebijakan: Pendekatan kuantitatif, kualitatif, kombinasi, R\&D, dan penelitian evaluasi. Alfabeta

Vanichchinchai, A. (2019). Quality management and supply chain management frameworks: A classification. Conference Paper on 8th International Conference on Industrial Technology and Management (ICITM), 22-25. https://doi.org//ICITM.2019.8710728

Widyacantika, S. A., \& Azis, A. M. (2020). Analisis penerapan manajemen rantai pasok ramah lingkungan pada PT X. Banking \& Management Review, 9 (1), 1264-1273. http://ojs.ekuitas.ac.id/index.php/bmr/article/view/267/156 